\title{
PERIKANAN DAN DINAMIKA POPULASI RAJUNGAN (Portunus pelagicus Linnaeus, 1758) DI TELUK JAKARTA
}

\section{FISHERY AND POPULATION DYNAMICS OF BLUE SWIMMER CRABS (Portunus pelagicus Linnaeus, 1758) IN JAKARTA BAY}

\author{
Karsono Wagiyo*1, Tirtadanu ${ }^{1}$ dan Tri Ernawati ${ }^{1}$ \\ ${ }^{1}$ Peneliti pada Balai Penelitian Perikanan Laut, Jl. Raya Bogor, Nanggewer Mekar, Cibinong, Bogor, \\ Jawa Barat-16912, Indonesia \\ Teregistrasi I tanggal: 24 Januari 2019; Diterima setelah perbaikan tanggal: 14 Agustus 2019; \\ Disetujui terbit tanggal: 20 September 2019
}

\begin{abstract}
ABSTRAK
Teluk Jakarta merupakan salah satu daerah penangkapan dan habitat rajungan (Portunus pelagicus) di Indonesia. Permintaan pasar yang terus meningkat dan bersamaan dengan penurunan kualitas perairan mengakibatkan stok rajungan mengalami tekanan eksploitasi dan degradasi habitat. Agar pengelolaan sumberdaya rajungan di Teluk Jakarta tetap lestari, maka diperlukan penelitian mengenai perikanan dan dinamika populasi. Tujuan penelitian memperoleh data dan informasi mengenai daerah tangkapan, alat dan musim penangkapan, indeks kelimpahan, produksi dan komposisi, struktur ukuran, nisbah kelamin, kematangan gonad, musim pemijahan, ukuran panjang pertama tertangkap, ukuran panjang pertama matang gonad, laju pertumbuhan, laju kematian dan laju eksploitasi. Data dan informasi diperoleh dengan eksplorasi, observasi, enumerasi, wawancara dan perunutan pada tempat pendaratan ikan dan instansi lain yang terkait dengan perikanan, selama tahun 2016. Hasil penelitian didapatkan karakteritik daerah penangkapan rajungan; substrat lumpur berpasir dengan perairan dasar yang mempunyai salinitas 30,5-32 ppt, oksigen 6,5-6,9 ml/l, pH 7,5-8,01, kecepatan arus 0,08-0,24 m/dt. Alat tangkap utama berupa jaring insang dasar bermata 3-3,5 inchi, musim penangkapan Mei-Agustus dan paceklik November-Januari. CPUE rajungan tahun 2016 sebesar $7,2 \mathrm{~kg} /$ tarik/trip/hari dan mengalami penurunan $55,22 \%$ tahun 2007. Rajungan berkontribusi $69,11 \%$ terhadap hasil tangkapan jaring insang dasar, sumberdaya ikan lainnya 30,89 \%. Modus lebar karapas $85-90 \mathrm{mmCW}$, lebar karapas pada perairan dekat pantai $84,3 \mathrm{~mm}$ dan kearah lepas pantai $99,4 \mathrm{~mm}$. Rajungan di Teluk Jakarta mempunyai tipe pertumbuhan alometrik negatif. Nisbah kelamin jantan : betina $=1: 0,83$, betina dominan pada perairan kearah lepas pantai dan jantan dominan kearah pantai (salinitas rendah). Musim pemijahan rajungan di Teluk Jakarta sepanjang tahun, mempunyai dua puncak pada bulan Maret dan September dengan pusat sebaran gonad ovigerous di sekitar perairan P. Damar. Rata-rata ukuran pertama tertangkap $(\mathrm{Lc})=93,87 \mathrm{mmCW}$ lebih besar dari rata-rata ukuran pertama matang gonad $(\mathrm{Lm})=68,8 \mathrm{mmCW}$. Laju pertumbuhan $(\mathrm{K})=1,08 \mathrm{mmCW} /$ tahun dengan lebar karapas maksimal $\left(\mathrm{L}_{\infty}\right)=142,5 \mathrm{mmCW}$. Laju kematian total $(Z)=4,87 /$ tahun, penangkapan $(F)=$ $3,63 /$ tahun, alami $(M)=1,24 /$ tahun dan laju pengusahaan $(E)=0,75 /$ tahun.
\end{abstract}

Kata Kunci: Rajungan; perikanan; dinamika populasi; Teluk Jakarta

\begin{abstract}
Jakarta Bay is one of the fishing areas and habitat of blue swimmer crabs (Portunus pelagicus) in Indonesia. Market demand that continues to increase and along with the decline in water quality results in crab stocks experiencing pressure from exploitation and habitat degradation. So that the management of crab resources in the Jakarta Bay remains sustainable, research on fisheries and population dynamics is needed. The purpose of the study was to obtain data and information; fishing ground, fishing season and main gears, abundance index, production and composition of catch, size structure, sex ratio, gonad maturity, spawning season, first length of catch, length of first gonad maturity, growth rate, mortality rate and exploitation rate. Data and information were obtained
\end{abstract}

Korespondensi penulis:

k_giyo@yahoo.co.id

DOI: http://dx.doi.org/10.15578/jppi.25.2.2019.79-92 
by exploration, observation, enumeration, interviews and tracing at fish landing sites and other institutions related to fisheries, during 2016. The results of the study obtained the characteristics of the crab fishing ground; sandy mud substrate with bottom waters which have a salinity of 30.5-32 ppt, oxygen 6.5-6.9 ml / I, pH 7.5-8.01, flow velocity 0.08-0.24 m/ sec. The main gears are bottom gill nets with mesh size 3-3.5-inch, the fishing season in May-August and famine in the NovemberJanuary. CPUE of blue swimmer crabs in the 2016 was $7.2 \mathrm{~kg} /$ pull / trip / day decreased 55.22\% in 2007. The blue swimmer crabs contributed $69.11 \%$ to the catch of bottom gill nets, other fish resources $30.89 \%$. Carapace width frequency have mode is $85-90 \mathrm{mmCW}$, carapace width in waters near the coast is $84.3 \mathrm{~mm}$ and offshore is $99.4 \mathrm{~mm}$. The blue swimmer crabs in Jakarta Bay has a negative allometric growth type. Sex ratio male: female $=1: 0.83$, female dominant in offshore and male dominant direction towards in shore and (low salinity). The spawning season of blue swimmer crabs in Jakarta Bay has two peaks in March and September with an ovigerous gonad distribution center around the waters of $P$. Damar. The average size of the length first catch $(L C)=$ 93.87 $\mathrm{mmCW}$ is greater than the average size of the length first gonad maturity $(L \mathrm{~m})=68.8$ $\mathrm{mmCW}$. Growth rate $(K)=1.08 \mathrm{mmCW} /$ year with length infinity of carapace width $\left(L_{\infty}\right)=142.5$ $\mathrm{mmCW}$. Maturity rate are total $(Z)=4.87 /$ year, capture $(F)=3.63 /$ year, natural $(M)=1.24 /$ year and explotation rate $(E)=0.75 /$ year .

\section{Keywords: Blue swimmer crabs; fishery; population dynamics; Jakarta Bay}

\section{PENDAHULUAN}

Rajungan (Portunus pelagicus) merupakan salah satu kelompok hewan krustasea, mempunyai kandungan gizi tinggi sebagai sumber protein pangan (Ubadillah \& Hersoelistyorini, 2010; Premarathna et al., 2015, sehingga rajungan bernilai ekonomis penting, karena permintaan pasar baik lokal maupun internasional. Rajungan tergolong hewan sedentary yang menempati habitat perairan dangkal di daerah pesisir (Johnston et al., 2011; Hamid et al., 2016), oleh karena itu rajungan rentan terhadap ekploitasi berlebih dan degradasi habitat.

Saat ini rajungan merupakan salah satu komoditas perikanan yang diperkirakan mengalami penurunan populasi akibat tekanan eksploitasi dan degradasi habitat/lingkungan (Johnston et al., 2011). Hal ini berdampak terhadap perubahan struktur populasi dan strategi reproduksi rajungan dengan parameter yang dapat berubah meliputi; ukuran pertama matang gonad menjadi lebih kecil, perubahan daerah dan musim pemijahan, perubahan keseimbang nisbah kelamin rajungan, jantan menjadi lebih tinggi (Arfah et al., 2005), penurunan GSI (Yuliani et al., 2015) dan perkembangan oogonia dan jumlah spermatozoa (Jalius, 2008). Seluruh perubahan tersebut akan mempengaruhi stok dan produksi rajungan serta kegiatan penangkapannya.

Di perairan Teluk Jakarta, tekanan ekploitasi rajungan disebabkan oleh kegiatan penangkapan intensif yang dilakukan nelayan tradisional (Nuraini et al., 2009) dengan indikasi penurunan hasil tangkapan per upaya (CPUE) (Panggabean et al., 2018). disamping adanya degradasi habitat yang diindikasikan dengan terjadinya pencemaran kronis logam berat (Anonim, 2004 dalam Sachoemar \&
Wahjono, 2007; Hayati et al., 2013; Anonim, 2017) dan adanya kematian masal ikan (termasuk rajungan) yang terjadi secara berulang (BPLHD, 2005; Putri et al., 2015).

Walaupun pemanfaatan sumber daya rajungan telah memperlihatkan terjadinya penurunan stok (CPUE), namun pengelolaan perikanan rajungan di Teluk Jakarta masih sangat jarang dikakukan. Penelitian ini dilakukan dengan tujuan memperoleh data dan informasi terbaru mengenai berbagai aspek perikanan dan dinamika populasi rajungan di Teluk Jakarta, dimana data tersebut dapat digunakan dalam pengelolaan sumber daya rajungan secara berkelanjutan.

\section{BAHAN DAN METODE Pengumpulan Data}

Data dikumpulkan pada tahun 2016, secara eksplorasi, observasi dan wawancara, enumerasi serta penelusuran data sekunder. Eksplorasi untuk memperoleh data parameter kondisi habitat rajungan. Observasi dan wawancara untuk memperoleh data komposisi jenis, tingkat kematangan gonad, seks rasio, spesifikasi alat, daerah dan trip penangkapan. Enumerasi dilakukan untuk perolehan data yang terkait panjang dan berat rajungan serta hasil tangkapan. Lokasi pendataan dilakukan di Cilincing dan penelusuran history data dilakukan untuk memperoleh data produksi secara berkala dan musim penangkapan. Sumber data antara lain; nelayan, kelompok usaha bersama nelayan, buku bakul, tempat pendaratan ikan dan Dinas Kelautan, Pertanian dan Ketahanan Pangan.

\section{Analisa sampel}

Tingkat kematangan gonad (TKG) diamati secara makroskopis mengikuti Sumpton et al., 1994 dalam 
Svane \& Hooper, 2004; de Lastang et al., 2003; Kamrani et al., 2010; Kumar et al., 2003) yang dirinci sebagai berikut;

TKG I = Dara, ovari tipis tampak putih terang

TKG II = Berkembang, ovari berwarna kuning muda tidak menyebar ke area hepatik

TKG III = Pematangan, ovari berwarna kuning menyebar meliputi 1/3-1/4 area hepatik

TKG IV = Matang gonad, ovari menyebar meliputi sebagian besar area hepatik berwarna orange kemerah-merahan.

TKG V = Ovigerous/berried

\section{Analisa Data}

Analisis indek musim penangkapan

$M=1 / t x \Sigma\left(\frac{\text { Produksi bulanan }}{\text { Produksi rata }- \text { rata bulanan }} \times 100\right)$

Keterangan;

$\mathrm{IM}$ = indek musim penangkapan

$\mathrm{t}=$ jumlah tahun.

Indeks kelimpahan/Catch per Unit effort (CPUE) dianalisis dengan

$$
\text { CPUE }=\frac{C W}{T}
$$

Keterangan;

$$
\begin{array}{ll}
\text { CPUE } & =\text { Catch per Unit Effort } \\
\mathrm{CW} & =\text { Berat hasil tangkapan } \\
\mathrm{T} & =\text { Trip penangkapan }
\end{array}
$$

Rata-rata ukuran panjang pertama kali matang gonad $(\mathrm{Lm})$ didapatkan dari analisis lebar karapas menggunakan grafik fungsi logistik menurut King (1995) dengan persamaan:

$P_{L m}=1 /(1+\exp (a L+b)$

Panjang pertama kali tertangkap (LC) didapatkan dari analisis fungsi logistik lebar karapas menurut Sparre \& Venema (1992) dengan persamaan :

$S_{L}=1 /\left(1+\exp \left(a-b^{*} L\right)\right.$

dimana; SL adalah selektivitas alat tangkap, a dan $\mathrm{b}$ adalah konstanta, $\mathrm{L}$ adalah panjang ikan dan nilai Lc diperoleh dari $\mathrm{a} / \mathrm{b}$.

Parameter pertumbuhan; koefisien pertumbuhan (K) dan panjang karapas infinity $\left(\mathrm{L}_{\infty}\right)$ diperoleh dari perunutan frekuensi panjang karapas dengan program FISAT II berdasarkan pada persamaan parameter pertumbuhan Von Bertalanffy yang menggambarkan pertambahan panjang sebagai fungsi dari umur (Sparre \& Venema, 1992) sebagai berikut:

$$
L t=L_{\infty}\left(1-e^{-K t(t-t o}\right)
$$

Keterangan;

Lt = panjang ikan saat umur ke-t $(\mathrm{cm})$

$\mathrm{L}_{\infty}=$ panjang asimtotik ikan $(\mathrm{cm})$ dan

$\mathrm{K}=$ laju pertumbuhan ikan.

Kematian total (Z)dianalisis dengan rumus Pauly (1980):

$\operatorname{Ln~N/t}=a-Z t$

Keterangan;

$\mathrm{N}$ = banyaknya ikan pada waktu $\mathrm{t}$

$\mathrm{t}=$ waktu yang diperlukan untuk tumbuh suatu kelas panjang dan

$\mathrm{a}=$ hasil tangkapan yang dikonversikan terhadap panjang.

Kematian alamiah (M) diduga dengan menggunakan rumus empiris Pauly (1980):

$\log M=-0,0066-0,279 \log L \propto+0,654 \log K+0,4534$ $\log \mathrm{T}$

Keterangan;

$M=$ laju kematian alamiah

$\mathrm{L}=$ panjang total maksimum $(\mathrm{cm})$

$\mathrm{K}$ = laju pertumbuhan (cm/tahun) dan

$\mathrm{T}=\operatorname{suhu}\left({ }^{\circ} \mathrm{C}\right)$.

Kematian karena penangkapan $(F)$ diperoleh dengan mengurangi laju kematian total $(Z)$ dengan laju kematian alami (M). Laju pengusahaan (E) diperoleh dari pembagian laju kematian karena penangkapan dengan laju kematian total.

\section{HASIL DAN BAHASAN \\ Hasil}

\section{Daerah Penangkapan}

Nelayan rajungan yang berbasis di Cilincing melakukan penangkapan rajungan pada 10 lokasi utama (Lampiran 1). Daerah tangkapan dapat dibedakan menjadi tiga zona habitat rajungan. Zona I merupakan habitat di area sekitar pantai/dalam Teluk Jakarta (Ancol, Pelabuhan, Tembakan, Kelip ijo, Sikutan dan Harmoni), Zona II merupakan habitat di area tengah Teluk Jakarta (Ancol Tengah dan Line Kapal) dan Zona III merupakan habitat di area luar Teluk Jakarta (P. Bulat dan P. Damar). 
Hasil pengukuran terhadap enam jenis parameter perairan pada masing-masing zona habitat tercantum pada Tabel 1. Parameter kondisi perairan menunjukkan pola degradasi peningkatan secara berurutan dari zona habitat pantai menuju zona habitat lepas pantai adalah kedalaman $(8,5 \mathrm{~m}, 17,8 \mathrm{~m}$ dan $22,3 \mathrm{~m})$, kecerahan $(4,2 \mathrm{~m}, 4,8 \mathrm{~m}$ dan $6,7 \mathrm{~m})$, salinitas dasar perairan ( 30,83 ppt, 31,17 ppt dan 31,67 ppt) dan pH dasar perairan ( 7,64; 7,79 dan 8,01). Parameter kondisi perairan yang pola degradasi tidak mengikuti zona habitat dari pantai menuju lepas pantai adalah oksigen terlarut dasar perairan $(6,80 \mathrm{ml} / \mathrm{l}, 6,73 \mathrm{ml} / \mathrm{l}$ dan 6,83 $\mathrm{ml} / \mathrm{l})$ dan kecepatan arus $(0,12 \mathrm{~m} / \mathrm{dt} ; 0,22 \mathrm{~m} / \mathrm{dt}$ dan $0,18 \mathrm{~m} / \mathrm{dt})$. Pengamatan substrat dasar perairan pada habitat rajungan di Teluk Jakarta, seluruhnya dijumpai tipe berlumpur.

Tabel 1. Nilai parameter kondisi perairan pada habitat rajungan (Portunus pelagicus)

Table 1. Parameter value of waters condition in the blue swimmer crab (P.pelagicus) habitat

\begin{tabular}{|c|c|c|c|c|c|c|c|c|c|c|}
\hline \multirow{2}{*}{\multicolumn{2}{|c|}{$\begin{array}{l}\text { Zona } \\
\text { Habitat }\end{array}$}} & \multirow{2}{*}{$\begin{array}{l}\text { Kedalaman } \\
\text { (m) }\end{array}$} & \multirow{2}{*}{$\begin{array}{l}\text { Kecerahan } \\
(\mathrm{m})\end{array}$} & \multicolumn{2}{|c|}{ Salinitas (ppt) } & \multicolumn{2}{|c|}{ Oksigen (ml/L) } & \multicolumn{2}{|c|}{ pH (skala) } & \multirow{2}{*}{$\begin{array}{c}\text { Arus } \\
\text { (m/dt.) }\end{array}$} \\
\hline & & & & Permukaan & Dasar & Permukaan & Dasar & Permukaan & Dasar & \\
\hline III & Kisaran & 20-25 & $3,6-8,3$ & & $31,5-32$ & & & $8,1-8,3$ & & $0,08-0,24$ \\
\hline & Rerata & 22.3 & 6.7 & 29.83 & 31.67 & 7.80 & 6.83 & 8.23 & 8.01 & 0.18 \\
\hline II & Kisaran & $16,7-18,4$ & $3,8-5,9$ & $28,5-30$ & $30,5-32$ & $6,2-10,1$ & $6,5-6,9$ & $7,7-8,3$ & $7,6-7,9$ & $0,16-0,27$ \\
\hline & Rerata & 17.8 & 4.8 & & & & & 8.17 & 7.79 & 0.22 \\
\hline I & $\begin{array}{l}\text { Kisaran } \\
\text { Rerata }\end{array}$ & $\begin{array}{c}7,8-9,5 \\
8.5\end{array}$ & $\begin{array}{c}2,1-6,8 \\
4.2\end{array}$ & $\begin{array}{c}29,5-30 \\
29.67\end{array}$ & $\begin{array}{c}30,5-31 \\
30.83\end{array}$ & $\begin{array}{c}10-11,5 \\
10.67\end{array}$ & $\begin{array}{c}6,6-7,0 \\
6.80\end{array}$ & $\begin{array}{c}8,2-8,4 \\
8.32\end{array}$ & $\begin{array}{c}7,5-7,7 \\
7.64\end{array}$ & $\begin{array}{c}0,07-0,20 \\
0.12\end{array}$ \\
\hline
\end{tabular}

\section{Alat Tangkap dan Musim Penangkapan}

Alat tangkap utama rajungan di perairan Teluk Jakarta adalah jaring rajungan (set bottom gillnet) dan bubu (trap) rajungan. Alat lain yang dapat menangkap rajungan adalah jaring apolo (seine net), jaring rampus, jaring cantrang (danish seiners) dan bagan. Dalam operasi penangkapan dengan jaring rajungan, satu unit terdiri dari 7-20 set jaring dan perahu. Masingmasing set (piece) mempunyai lebar \pm 0,4-0,6 m (22 mata) dan panjang $150 \mathrm{~m}$. Mata jaring rajungan 3-3,5 inchi. Perahu yang digunakan mempunyai tonase lebih kecil dari 5 GT dengan mesin 8 PK.

Hasil ektrapolasi dari data di tempat pendaratan ikan Cilincing didapatkan indeks musim penangkapan rajungan pada Lampiran 2. Musim penangkapan MeiAgustus dan Oktober. Musim paceklik berlangsung November-Januari dan September.

\section{Indeks Kelimpahan, Produksi dan Komposisi Jenis Tangkapan Jaring Rajungan}

Ekstrapolasi hasil tangkapaan jaring rajungan mendapatkan indeks kelimpahan stok (CPUE) rajungan seperti disajikan pada Lampiran 3. CPUE bulanan rata-rata $7,2 \mathrm{~kg} /$ tarik/trip/hari dengan nilai terkecil 4,8 kg/tarik/trip/hari pada November 2015 dan terbesar 9,4 kg/tarik/trip/hari pada Mei 2016 (Lampiran 3a). CPUE rajungan tahunan pada tahun 2007 sebesar $15,9 \mathrm{~kg} /$ tarik/trip/hari, turun secara linier menjadi 7,12 $\mathrm{kg} /$ tarik/trip/hari pada tahun 2016 (Lampiran 3b). Produksi rajungan secara bulanan tercantum pada Lampiran 4a. Produksi bulanan rajungan terkecil terjadi pada bulan November $3.445 \mathrm{~kg}$, terbesar pada bulan Mei 5.648,11 kg dan rata-rata bulanan 4.409,6 $\mathrm{kg} / \mathrm{bulan}$.
Hasil tangkapan jaring rajungan yang dominan adalah Portunus pelagicus 54,78 \% dan anggota portunidae lainnya 14,33\% (Lampiran 4b). Ikan demersal adalah ikan yang dominan hasil tangkapan jaring rajungan antara lain; Sciaenidae 6,87\%, Ariidae 5,93 $\%$ dan Dasyatidae 5,31 \%. Kelompok krustasea non kepiting yang dominan tertangkap jaring rajungan adalah familia Scyllaridae 3,19\%.

\section{Struktur Ukuran, Nisbah Kelamin dan Kematangan Gonad}

Sebaran frekuensi lebar karapas mempunyai modus pada kelas lebar 85-90 mmCW (Lampiran 5a). Ukuran lebar karapas terkecil 51,30 mmCW, terbesar $134,0 \mathrm{mmCW}$ dengan rata-rata $87,78 \mathrm{mmCW}$. Ukuran berat rajungan rata-rata 50,06 g., terkecil $9 \mathrm{~g}$. dan terbesar $159 \mathrm{~g}$. Hubungan lebar karapas-berat rajungan (Portunus pelagicus) mempunyai sifat allometrik negatif dengan nilai $b=2,8794, R^{2}=0,8547$ (Lampiran 5b).

Sebaran spasial lebar karapas rajungan kearah perairan lebih dalam dan kearah lepas pantai ditemukan lebih besar, dibandingkan pada lokasi mendekati pantai dengan perairan dangkal (Lampiran 5c). Ukuran lebar karapas terbesar di jumpai di P. Damar dengan rerata 99,4 $\mathrm{mm}$ dan deviasi 9,9 mm. Lokasi penangkapan pantai Ancol mempunyai ukuran lebar karapas terkecil dengan rerata $84,3 \mathrm{~mm}$ dan deviasi 9,4 $\mathrm{mm}$.

Pengamatan terhadap 2.284 ekor rajungan dari perairan Teluk Jakarta didapatkan rasio jantan: betina $=1: 0,83$. Nisbah kelamin rajungan bervariasi secara bulanan (Lampiran 6a). Rajungan betina mempunyai rasio lebih tinggi dibandingkan jantan, terjadi pada 
September dan Oktober, sebalik pada bulan lainnya jantan lebih tinggi. Rasio rajungan betina tertinggi terjadi pada Oktober (64,83\%: 35,17\%). Rasio rajungan jantan tertinggi terjadi pada November $(75,87$ $\%: 24,13 \%$ ).

Sebaran spasial nisbah kelamin menunjukkan rasio betina lebih besar pada lokasi yang mengarah ke arah lepas pantai, sedangkan rasio jantan lebih besar ditemukan pada lokasi mengarah ke arah pantai (Lampiran 6b). Lokasi dengan rasio betina lebih besar antara lain P. Bulat, P. Damar dan Ancol Tengah, dengan kontribusi populasi betina masing-masing sebesar $86,67 \%, 73,33 \%$ dan $57,65 \%$. Lokasi yang mempunyai rasio jantan lebih besar antara lain Sikutan, Tambakan dan Pantai Ancol dengan kontribusi masing-masing sebesar $81,34 \%, 80 \%$ dan $74,67 \%$.

Hasil pengamatan tingkat kematangan gonad terhadap 1.061 ekor rajungan, tercantum pada Lampiran 7a. Pada bulan Maret komposisi TKG meliputi TKG I 10,1\%, TKG II 4,19\% dan TKG III $15,51 \%$, TKG IV $20,2 \%$ dan berried $50 \%$. Pada Mei komposisi TKG meliputi TKG I 71,43\%, TKG II 24,29 $\%$ dan TKG III 4,08 \%. Pada September komposisi TKG meliputi TKG I 23,1 \%, TKG II 12,3\%, TKG III $29,2 \%$ dan barried $35,4 \%$. Pada Oktober komposisi TKG meliputi TKG I 21,28 \%, TKG || 23,40 \% dan TKG III 43,62\%, TKG IV 11,70\%.

Komposisi TKG V/berried/ovigerous gonad rajungan semakin besar menuju pada lokasi penangkapan kearah lepas pantai dan perairan yang lebih dalam (Lampiran 7b). Lokasi yang memiliki komposisi ovigerous gonad tinggi antara lain; P. Bulat, P. Damar dan Ancol Tengah masing-masing $28,21 \%$, $27,27 \%$ dan $26,53 \%$ dari populasi rajungan betina. Komposisi ovigerous gonad rendah dijumpai pada lokasi penangkapan di Tembakan, Sikutan dan Kelip ljo masing-masing $0 \%, 4 \%$ dan $8,33 \%$.

Rata-Rata Ukuran Panjang Pertama Tertangkap (Lc), Rata-Rata Ukuran Panjang Pertama Matang Gonad (Lm), Laju Kematian(M)dan Laju Eksploitas(E)

Rajungan yang diamati di tempat pendaratan Cilincing didapatkan pertama kali tertangkap (LC) pada ukuran lebar karapas 93,87 mmCW (Lampiran 8a). Sementara itu rata-rata ukuran rajungan pertama matang gonad terjadi pada lebar karapas $68,8 \mathrm{mmCW}$.

Sebaran frekuensi lebar karapas rajungan di perairan Teluk Jakarta menunjukkan modus yang berbeda sesuai dengan bulan pengamatan (Lampiran 8b). Garis yang menghubungkan antar sebaran frekuensi lebar karapas bulanan menunjukkan adanya pergeseran modus. Pelacakan garis modus pertumbuhan dengan model Von Bertalanfly diperoleh laju pertumbuhan $(K)=1,08$ per tahun dan panjang asimtotik (L") sebesar 142,5 mmCW.

Hasil estimasi nilai laju kematian total ( $Z$ ) dengan linierisasi parameter pertumbuhan $\mathrm{K}$ dan L", diperoleh grafik slope kemiringan dengan nilai $Z=4,87$ (Gambar 8c). Dugaan kematian alami (M) dengan perhitungan formula Pauly (1980) diperoleh nilai 1,24/tahun, nilai laju kematian karena penangkapan $(F)$ sebesar 3,63/ tahun dan nilai laju pengusahaan $(E)$ sebesar 0,75 / tahun.

\section{Bahasan}

Daerah tangkapan rajungan tersebar luas di Teluk Jakarta, karena perairannya mempunyai karakteristik habitat yang diperlukan rajungan. Karakteristik habitat rajungan merupakan perairan pesisir yang dangkal dengan pulau-pulau kecil dan memiliki substrat dasar pasir lumpur-lumpur berpasir (Johnston et al., 2010). Hasil penelitian Sluiter dalam Soegiarto \& Soegiarto (1977) dan Wagiyo (2008) menemukan substrat dasar perairan Teluk Jakarta didapatkan lumpur berpasir pasir berlumpur.

Alat tangkap utama rajungan di perairan Teluk Jakarta berupa jaring insang dasar (jaring rajungan). Operasional alat tangkap ini menggunakan teknologi sederhana dan pengusahaannya dilakukan dengan skala rakyat (de la Cruz et al., 2015). Jenis alat ini umum digunakan pada berbagai perairan seperti di India (Josileen \& Menon, 2007) dan di Thailand (Songrak et al., 2013). Kesederhanaan teknologi dan pengusahaan, berhubungan dengan tipe habitat dan sebaran rajungan yang dekat pantai (de la Cruz et al., 2015).

Musim puncak penangkapan rajungan di Teluk Jakarta berlangsung April s/d Agustus dengan puncak Mei sama dengan di perairan Pankajene Kepulauan (Wiyono \& Ihsan,2018). Di Thailand, puncak musim penangkapan berlangsung pada Desember-Januari dan Juni-Juli (Kunsook et. al., 2014). Sementara di Australia Selatan tertinggi pada Februari-Maret dan September-Oktober (Svane \& Hooper, 2004). Perbedaan bulan musim penangkapan karena adanya kondisi iklim yang berbeda antar wilayah geografi. Hasil penelitian Kunsook et al. (2014) dan Svane \& Hooper (2004), puncak musim penangkapan rajungan bersamaan dengan terjadinya musim kering. Pada periode April-Agustus, di perairan Teluk Jakarta merupakan bulan kering (Kida \& Richards, 2009; 
Setiawan \& Habibi, 2010). Pada penelitian ini berlangsungnya musim penangkapan rajungan berbeda bulan dengan berlangsungnya musim pemijahan yaitu pada Maret dan September. Perbedaan ini dapat mengurangi tekanan penangkapan terhadap induk, sehingga kelestarian reproduksi dapat lebih baik.

CPUE rajungan di perairan Teluk Jakarta dari tahun 2007 ke tahun 2016 telah mengalami penurunan sebesar $55,22 \%$. Pada tahun 2016, CPUE bulanan bervariasi dengan rata-rata $7,2 \mathrm{~kg} /$ tarik/trip/hari. Penurunan CPUE ini disebabkan karena pencemaran lingkungan dan tekanan eksploitasi. Hal ini sesuai dengan yang dinyatakan oleh Hayati et al. (2013) bahwa pencemaran lingkungan dan kegiatan ekonomi di sekitar perairan Teluk Jakarta semakin meningkat. Kecenderungan terjadinya penurunan populasi rajungan juga terjadi di Australia (Johnston et al., 2010). Puncak CPUE dan musim penangkapan rajungan antar wilayah dan antar negara, dapat terjadi pada bulan yang berbeda. Puncak CPUE di Teluk Jakarta terjadi pada Mei sebesar 9,4 kg/trip/tarik/hari, berbeda dengan di perairan bagian utara Teluk Persia CPUE tinggi terjadi antara Juni-September dan rendah Januari-Maret (Safaie et al., 2015). CPUE rajungan di Teluk Jakarta tergolong tinggi jika dibandingkan di perairan Dar es Salaam-Tanzania 1,08-2,24 kg/tarik (Chande \& Mgaya, 2003). Perbedaan kelimpahan antar bulan dipengaruhi oleh kebiasaan makan, pertumbuhan, umur, reproduksi, multing (ganti kulit) dan migrasi (Hosseini et al., 2012). Kelimpahan lebih tinggi terjadi pada musim kering dibandingkan musim penghujan (Kunsook et al., 2014)). Hal serupa terjadi di Tanzania (Chande \& Mgaya, 2003) dan di Australia (Potter \& de Lastang, 2000) bahwa kelimpahan rajungan lebih tinggi pada musim penghangatan suhu dibandingkan musim penurunan suhu.

Di Teluk Jakarta Portunidae merupakan hasil tangkapan jaring rajungan (jaring insang dasar) yang dominan sebesar $69,11 \%$ (rajungan $79,26 \%$ dan portunid lainnya $20,74 \%$ ). Hasil tangkapan jaring rajungan lainnya berupa ikan dan sumberdaya perikanan lainnya sebesar $30,89 \%$. Tertangkapnya ikan dan krustasea lainnya dalam jaring insang dasar dimungkinkan karena preferensi habitat yang sama dengan rajungan. Kontribusi rajungan di Teluk Jakarta, lebih besar dari pada perairan lainnya seperti di Tanzania dengan kisaran 39,1-81,5\% (Chande \& Mgaya, 2003). Safaie et al. (2015) di Teluk Persia mendapatkan total portunid meliput 9,27 \% dan diantaranya $68,59 \%$ merupakan rajungan. Rajungan dominan pada hasil tangkapan ini, disebabkan alat dan teknik operasional penangkapan ditujukan untuk menangkap rajungan. Jaring dibuat dari bahan monofilamen dengan ukuran mata yang besar serta perendaman jaring terletak diatas dasar perairan yang mempunyai substrat pasir berlumpur pada area yang berdekatan dengan ekosistem hutan, terumbu karang, padang lamun dan hamparan alga.

Ukuran karapas rajungan di Teluk Jakarta lebih kecil dibandingkan dari berbagai hasil penelitian terdahulu di berbagai perairan, baik di Indonesia (Prihatiningsih \& Wagiyo, 2009; Sara et al., 2016; Ningrum et al., 2015 \& Ihsan et al., 2014) maupun di perairan berbagai negara (Kunsook et al., 2014; Kamrani et al., 2010 \& Dineshbabu et al., 2007). Perbedaan ukuran dapat disebabkan oleh tipe habitat, kondisi lingkungan dan letak geografis (Potter \& de Lastang, 2000). Rajungan hasil tangkapan asal perairan Teluk Jakarta mempunyai sifat pertumbuhan alometrik negatif sama dengan hasil penelitian Prihatiningsih \& Wagiyo (2009) di perairan Tangerang. Sifat pertumbuhan bisa berbeda antar musim dan antar lokasi; sifat pertumbuhan yang sama ditemukan di perairan Tangerang (Prihatiningsih \& Wagiyo, 2009), berbeda dengan di Iran bersifat isometrik (Kamrani et al., 2010) dan di India bersifat alometrik positif (Dineshbabu et al., 2007). Perbedaan sifat pertumbuhan dapat karena kondisi lingkungan/ ketersediaan makan, dan fase kehidupan. Di Teluk Jakarta, rajungan dengan lebar karapas lebih besar dijumpai di perairan yang relatif lebih dalam dan rajungan dengan ukuran kecil dijumpai di perairan dangkal. Hal ini sesuai dengan hasil penelitian Nitiratsuwan et al. (2010) rajungan muda dekat pantai dan dewasa menjauhi pantai. Liu et al. (2014) menyatakan variasi ukuran rajungan dapat disebabkan perbedaan lokasi penangkapan. Di perairan Australia (Svane \& Hooper, 2004) dan di perairan Tanzania (Joel \& Raj 1987 dalam Chande \& Mgaya, 2003) mendapatkan rajungan kecil di perairan pantai dan rajungan besar bermigrasi kearah lepas pantai.

Populasi rajungan di perairan Teluk Jakarta mempunyai nisbah kelamin jantan: betina $=1: 0,83$ yang bervariasi secara bulanan. Nisbah kelamin dapat sama atau berbeda antar lokasi (Hosseini et al., 2012). Hasil yang sama ditemukan di perairan Teluk Persia Utara (Kamrani et al., 2010), sementara hasil yang berbeda ditemukan di perairan PangkepSulawesi Selatan dengan rasio betina : jantan $=1,2$ : 1 (Ihsan et al., 2014). Perbedaan nisbah kelamin disebabkan oleh berbagai faktor. Menurut Sara et al. (2016) nisbah kelamin dipengaruhi oleh; lokasi, pola migrasi, aktifitas reproduksi dan ukuran karapas. Menurut Weng (1992) dalam Kamrani et al. (2010), perbedaan nisbah kelamin antara lokasi disebabkan adanya perbedaan preferensi habitat rajungan jantan dan betina. 
Rajungan di perairan Teluk Jakarta mempunyai gonad matang sepanjang waktu pengamatan dengan persentase tertinggi pada bulan Maret dengan gonad matang $35,70 \%$ dan barried $50 \%$, pada September dengan gonad matang $29,2 \%$ dan barried $35,4 \%$. Ini menunjukkan rajungan memijah sepanjang tahun dengan dua puncak pada Maret dan September. Puncak pemijahan rajungan di perairan Teluk Jakarta berlangsung pada Maret dan September, ini berbeda dengan di Teluk Persia Utara yang berlangsung pada Desember (Kamrani et al., 2010) dan di Cina Selatan yang berlangsung pada April (Liu et al., 2014). Puncak pemijahan rajungan pada berbagai lokasi walaupun berlangsung pada bulan yang berbeda, tetapi mempunyai kesamaan kondisi perairan yaitu dalam keadaan menghangat, baik di perairan tropis (Ernawati et al., 2014 \& Zairion et al., 2015) maupun di perairan sub tropis (Kumar et al., 2003; Potter\& de Lastang, 2000 \& Johnson, et al., 2010). Adanya dua puncak pemijahan rajungan di Teluk Jakarta berhubungan dengan pola penghangatan perairan yang terjadi di Indonesia. Pada bulan Maret dan September perairan di Indonesia mengalami penghangatan dari bulan sebelumnya (Kida \& Richards, 2009, Setiawan \& Habibi, 2010). Pada lokasi lain di Indonesia dua puncak pemijahan rajungan, ditemukan juga di perairan Lampung Timur pada bulan April dan Oktober (Zairion et al., 2015).

Sebaran spasial rajungan ovigerous di Teluk Jakarta menunjukkan pada lokasi penangkapan yang menuju lepas pantai (P. Bulat, P. Damar dan Ancol Tengah) mempunyai kontribusi tinggi dan pada lokasi menuju pantai (Tembakan, Sikutan dan Kelip ljo) mempunyai kontribusi rendah. Penyebaran ini dimungkinkan perairan sekitar P. Bulat, P. Damar dan Ancol Tengah mempunyai dasar yang lebih dalam dan salinitas lebih tinggi dibandingkan lokasi lainnya, sedangkan di perairan di sekitar Tembakan, Sikutan dan Kelip ljo mempunyai dasar dangkal dan salinitas rendah. Menurut Batoy 1980 dalam Safaie et al. (2015) dan Kamrani et al. (2010), rajungan betina ovigerous bermigrasi ke perairan yang lebih dalam karena adanya salinitas yang lebih tinggi.

Rata-rata ukuran rajungan pertama tertangkap (LC) di Teluk Jakarta lebih besar dari rata-rata ukuran pertama matang gonad (Lm), menunjukkan bahwa hasil tangkapan rajungan dari berbagai alat tangkap yang beroperasional di perairan Teluk Jakarta masih layak tangkap. Lc rajungan di Teluk Jakarta lebih kecil dari di perairan Demak $122 \mathrm{mmCW}$ (Ningrum et al., 2015). Rajungan di Teluk Jakarta mempunyai $\mathrm{Lm}=$ $68,8 \mathrm{mmCW}$, lebih kecil dibandingkan dari berbagai perairan baik di Indonesia (Sara et al., 2014; Ihsan et al., 2014 \& Ernawati et al., 2014) maupun hasil penelitian di luar negeri (Potter \& de Lestang, 2000; Dineshbabu et al., 2007; Liu et al., 2014 \& Kunsook et al., 2014. Lm kecil, merupakan bagian dari strategi/ adaptasi hidup rajungan dalam menghadapi tekanan penangkapan dan pencemaran lingkungan di perairan Teluk Jakarta. Ukuran pertama matang gonad menunjukkan trend terbalik dengan suhu perairan, di daerah tropis rajungan memiliki ukuran pertama matang gonad lebih kecil dibandingkan di perairan subtropis (Liu et al., 2014).

Rajungan di Teluk Jakarta tergolong mempunyai laju pertumbuhan tinggi dan pencapaian maksimum lebar karapas tergolong rendah baik di perairan Indonesia lainnya (Kembaren et al., 2012; Ihsan et al., 2014 \& Ernawati et al., 2015) maupun di perairan lainnya di luar negeri (Dineshbabu et al., 2007; Kamrani et al., 2010; Mehanna et al., 2013 \& Afzaal et al., 2016).. Rajungan yang memiliki pertumbuhan lebih rendah dibandingkan Teluk Jakarta adalah di perairan Bone dengan nilai $\mathrm{K}=1,08$ /tahun $\mathrm{mmCW}$ dan di Teluk Persia Utara dengan nilai $\mathrm{K}=0,98$ /tahun ( Kamrani et al., 2010). Pencapaian lebar karapas maksimal dari rajungan di Teluk Jakarta ( $L "=142,5$ $\mathrm{mmCW}$ ), rendah dibandingkan di berbagai lokasi antara lain; di Bone nilai L" $=159 \mathrm{mmCW}$ (Kembaren et al., 2012), di Pati dengan nilai L" $=185 \mathrm{mmCW}$ (Ernawati et al., 2015) dan di Laut Arab dengan nilai $\mathrm{L}^{\prime \prime}=178,5 \mathrm{mmCW}$ (Afzaal et al., 2016). Perbedaan nilai L" dan $\mathrm{K}$ antar lokasi dapat disebabkan oleh perbedaan pencapaian umur (life span), suhu perairan dan tekanan penangkapan (Oh et al., 1999).

Laju kematian rajungan di Teluk Jakarta tergolong tinggi, baik karena penangkapan dengan nilai $F=3,63$ / tahun maupun kematian alami dengan nilai $M=1,24$ / tahun dibandingkan di Buton dengan nilai $F=1,71 /$ tahun dan nilai $\mathrm{M}=1,09 /$ tahun (Hamid \& Wardiatno, 2015). Di Teluk Persia Utara dengan nilai $M=1,05$ / tahun dan nilai $F=1,08 /$ tahun (Ehsan et al., 2010). Perbedaan laju kematian antar perairan disebabkan adanya perbedaan tekanan penangkapan dan kondisi lingkungan. Hasil penelitian Hayati et al. ( 2013) menunjukkan perairan Teluk Jakarta sudah mengalami pencemaran kronis.

Rajungan di Teluk Jakarta mempunyai laju pengusahaan $(E)=0,75$ /tahun), nilai ini sesuai dengan kriteria Sparre \& Venema, (1999) menunjukkan penangkapan berlebih, karena mempunyai laju pengusahaan $(E)>0,5 /$ tahun. Nilai ini lebih tinggi dibandingkan pada berbagai perairan di luar negeri (Dineshbabu et al.,2007; Kamrani et al., 2010; Kunsook et al., 2014 \& Afzaal et al., 2016) maupun perairan di Indonesia (Ihsan et al., 2014 \& Hamid \& Wardiatno, 2015). Perairan lain di Indonesia yang 
mempunyai laju pengusahaan lebih tinggi adalah perairan Pati dengan nilai $E=0,81$ /tahun untuk jantan dan 0,82/tahun untuk betina (Ernawati et al., 2015) dan perairan Bone dengan nilai $E=0,78$ /tahun untuk jantan dan $\mathrm{E}=0,82$ /tahun untuk betina (Kembaren et al., 2012). Perbedaan laju pengusahaan antar lokasi terjadi karena perbedaan intensitas penangkapan.

\section{KESIMPULAN}

Penangkapan rajungan di Teluk Jakarta pada daerah perairan yang mempunyai karakteristik, substrat dasar lumpur berpasir, salinitas 30,5-32 ppt, oksigen 6,5-6,9 ml/l, $\mathrm{pH} 7,5-8,01$, kecepatan arus 0,08-0,24 m/dt dan dilakukan secara tradisional dengan alat tangkap utama jaring insang dasar (jaring rajungan). Musim penangkapan berlangsung sepanjang tahun dengan puncaknya Mei-Agustus. Hasil tangkapan per unit usaha telah mengalami penurunan 55,22 \% dari tahun 2007 , dengan komposisi tangkapan berupa rajungan sebesar 69,11 $\%$ dan sumberdaya ikan lainnya 30,89 \%. Rajungan di Teluk Jakarta mempunyai tipe pertumbuhan alometrik negatif, lebar karapas kecil berada dekat pantai (Pantai Ancol), bertambah besar kearah lepas pantai (sekitar P. Damar). Nisbah kelamin rajungan jantan lebih besar dibandingkan betina dan rajungan betina dominan pada perairan kearah lepas pantai dan jantan dominan kearah pantai (salinitas rendah). Musim pemijahan rajungan di Teluk Jakarta sepanjang tahun dengan dua puncak pada Maret dan September dengan sebaran rajungan yang mengerami telur (ovigerous) terpusat di sekitar perairan P. Damar. Ukuran rajungan pertama tertangkap dengan jaring rajungan lebih besar dari ukuran pertama matang gonad, menunjukkan mata jaring yang digunakan sudah layak. Rajungan di Teluk Jakarta telah mengalami tekanan penangkapan dan lingkungan yang ditunjukkan oleh laju kematian karena penangkapan tinggi, laju pengusahaan tinggi, laju pertumbuhan tinggi dengan pencapaian ukuran maksimum rendah dan laju kematian alami tinggi. Sumberdaya rajungan di Teluk Jakarta perlu dilestarikan dengan menurunkan tingkat pengusahaan sampai dengan kondisi optimum. Selain itu juga perlu dicegah adanya peneningkatan pelumpuran substrat dasar pada daerah penangkapan/habitat rajungan dan mencegah pencemaran lingkungan.

\section{PERSANTUNAN}

Data yang digunakan dalam penulisan karya tulis ilmiah ini dikumpulkan dengan menggunakan anggaran APBN kegiatan penelitian Balai Penelitian Perikanan Laut tahun 2016. Diucapkan terima kasih kepada para peneliti dan karyawan Balai Penelitian
Perikanan Laut yang telah membantu tersusunnya karya tulis ilmiah ini.

\section{DAFTAR PUSTAKA}

Afzaal, Z., Kalhoro, M. A., Buzdar, M. A., Nadeem, A., Saeed, F., Haroon, A., \& Ahmed, I. (2016). Stock assessment of blue swimming crab Portunus pelagicus (Linnaeus, 1758) from Pakistani Waters (Northern, Arabian Sea). Pakistan J. Zool, 48(5), 1531-1541.

Anonim. (2017). Pemerintah dan Para Pakar Seperti tak Peduli lagi. http://www.pelita.or.id/ baca. php?id=70780.

Arfah, H., Mariam, S., \& Alimudin. (2005). Pengaruh suhu terhadap reproduksi dan nisbah kelamin ikan gapi (Poecilia reticulata Peters). Jurnal Akuakultur Indonesia, 4(1), 1-4.

Banks, R., \& Trumble, R.J. (2011). Pre-assessment of the Thailand Blue Swimming Crab (Portunus pelagicus) Fishery. Marine Resources Assessment Group Americas.

BPLHD (2005). Laporan status lingkungan hidup daerah khusu ibu kota Jakarta tahun 2004-2005.

Chande, A.I., \& Mgaya, Y.D. (2003). The fisherhy of Portunus pelagicus and species diversity of portunid crabs along the coast of Dar es Salaam, Tanzania. Western Indian Ocean J. Mar. Sci, 2(1), 75-84. DOI: 10.4314/wiojms.v2i1.28431.

de la Cruz, M.T., John O., de la Cruz, J.O., Tan, I.L., \& Ruizo, E.K. (2015). The blue swimming crab (Portunus pelagicus) fishery of Eastern Visayas, Philippines. Phil. J. of Nat. Sci, 20-1, 25-45.

de Lastang, S., Hall, N.G., \& Potter, I.C. (2003). Reproductive biology of the blue swimmer crab (Portunus pelagicus, Decapoda:Portunidae) in five bodies of water on the west coast of Australia. Fish.Bull.101, 745-757.

Dineshbabu, A. P., Sreedhara, B., \& Muniyappa, Y. (2007). Fishery and stock assessment of Portunus sanguinolentus (Herbst) from south Karnataka coast, J. Mar. Biol. Ass. India, 49 (2), 134-140.

Ehsan, K., S.A. Nabi., \& Y. Maziar. (2010). Stock assessment and reproductive biology of the blue swimming crab, Portunus pelagicus in Bandar Abbas Coastal Waters, Northern Persian Gulf. Journal of the Persian Gulf, 1(2), 11-22. 
Ernawati, T., Boer, M., \& Yonvitner. (2014). Biologi populasi rajungan (Portunus pelagicus) di perairan sekitar Pati, Jawa Tengah. BAWAL. 6(1), 31-40. DOI: 10.15578/bawal.6.1.2014.31-40

Ernawati, T., Wedjatmiko., \& Suman, A. (2015). Kajian parameter populasi dan tingkat pemanfaatan rajungan (Portunus pelagicus Linnaeus 1758) di Perairan Pati dan sekitarnya. J.Lit.Perikan.Ind, 21(3), 169-176.

Hamid, A., \& Wardiatno, Y. (2015). Population dynamics of the blue swimming crab (Portunus pelagicus Linnaeus, 1758) in Lasongko Bay, Central Buton, Indonesia. Aquaculture, Aquarium, Conservation \& Legislation International Journal of the Bioflux Society. 8(5),729-739.

Hamid, A., Wardiatno, Y., Lumbanbatu, D.T.F., \& Riani, E. (2016). Stock status and fisheries exploitation of blue swimming crab Portunus pelagicus (Linnaeus 1758) in Lasongko Bay Buton, Indonesia. Asian Fisheries Science, 29, 206-219.

Hayati, B.S., Sanim, B., Riani, E., Ardianto, L., \& Sutrisno, D. (2013). Valuasi ekonomi dampak pencemaran dan Analiss kebijakan pengendalian pencemaran di Teluk Jakarta. Globe, 15(2), 185 190.

Hosseini, M., Vazirizade, A., Parsa, Y., \& Mansori, A. (2012). Sex ratio, size distribution and seasonal abundance of blue swimming crab, Portunus pelagicus (Linnaeus, 1758) in Persian Gulf Coast, Iran. World Applied Science Journal, 17(7), 919925.

Ihsan, Wiyono, E.S., Wisudo, S.H., \& Haluan, J. (2014). A study of biological potential and sustainability of swimming crab population in the waters of Pangkep Regency South Sulawesi Province. International Journal of Sciences: Basic and Applied Research, 16(1), 351-363.

Johnson, D.D., Gray, C.A., \& Macbeth, W.G. (2010). Reproductive Biology of Portunus pelagicus in Sout-East Australian Estuary. Journal of Crustacean Biology, 30(2), 200-205.DOI:10.1651/083076.1 .

Johnston, D., Harris, D., Caputi, N., \& Thomson, A. (2010). Decline of a blue swimmer crab (Portunus pelagicus) fishery in Western Australia-History, contributing factors and future management strategy. Fisheries Research Journal homepage: www. elsevier.com/locate/fisheries.
Johnston, D., Harris, D., Caputi, N., \& Thomson, A. (2011). Decline of a blue swimmer crab (Portunus pelagicus) fishery in Western Australia-History, contributing factors and future management strategy. Fisheries Research, 109, 119-130. doi:10.1016/j.fishres.2011.01.027

Jalius, Setiyanto, D.D., Sumantadinata, K., Riani, E., \& Ernawati, Y. (2008). Bioakumulasi logam berat dan pengaruhnya terhadap oogenesis kerang hijau Perna viridis. J. Ris. Akuakultur Vol.3 No.1 4352. DOI: http://dx.doi.org/10.15578/jra.3.1.200.4352.

Josileen, J., \& Menon, N.G. (2007). Fishery and growth parameters of the blue swimmer crab Portunus pelagicus (Linnaeus, 1758) along the Mandapam coast, India. J. Mar. Biol. Ass. India, 49 (2), 159 165.

Kamrani, E., Sabili, A.N., \& Yahyavi, M. (2010). Stock assessment and reproductive biology of the blue swimming crab, Portunus pelagicus in Bandar Abbas Coastal Waters, Nothern Persian Gulf. Journal of Persian Gulf. 1(2), 11-22.

Kembaren, D.D., Ernawati, T., \& Suprapto. (2012). Biologi dan parameter populasi rajungan (Portunus pelagicus) di perairan Bone dan Sekitarnya. J. Lit. Perikan. Ind. 18(4),273-281. DOI: 10.15578/ jppi.18.4.2012.273-281

Kida, S., \& Richards, K.J. (2009). Seasonal sea surface temperature variability in the Indonesian Seas. Journal of geophysical research,114,C06016,doi:10.1029/2008JC005150.

Kumar, M.S., Xiao, Y., Venema, S., \& Hooper, G. (2003). Reproductive cycle of the blue swimmer crab, Portunus pelagicus, off southern Australia. J. Mar. Biol. Ass. U.K. 83, 983-994.

Kunsook, C., Gajaseni, N., \& Paphavasit, N. (2014). A stock assessment of the blue swimming crab Portunus pelagicus (Linnaeus, 1758) for Sustainable Management in Kung Krabaen Bay, Gulf of Thailand. Tropical Life Sciences Research, 25(1), 41-59.

Liu, Z., Wu, X., Wang, W., Yan, B., \& Cheng, Y. (2014). Size distribution and monthly variation of ovarian development for the female blue swimmer crab, Portunus pelagicus in Beibu Gulf, off south China. Scientia Marina, 78(2), 257-268. doi:10.1016/j.fishres.2011.01.027. 
Mehanna, S.F., Khvorop, S., Al-Sinawy, M., Al-Nadabi, Y.S., \& Al-Mosharafi, M.N. (2013). Stock assessment of the blue swimmer crab Portunus pelagicus (Linnaeus, 1766) from theOman Coastal Waters. International Journal of Fisheries and Aquatic Sciences, 2(1), 1-8.

Nitiratsuwan, T., Nitithamyong, C., Chiayvareesajja, S. \& Somboonsuke, B. (2010). Distribution of blue swimming crab (Portunus pelagicus Linnaeus, 1758) in Trang Province. Songklanakarin J. Sci. Technol. 32 (3), 207-212.

Nuraini, S., Prihatiningsih., \& Hartati, S.T. (2009). Parameter populasi dan selektivitas rajungan (Portunus pelagicus Linnaeus,1758) yang tertangkap dengan beberapa jenis alat tangkap di Teluk Jakarta. J.Lit.Perikan.Ind. 15(4). $287-295$. D O I: h t t p://dx.doi.org/10.15578/ jppi.15.4.2009.287-295.

Ningrum, V.P., Ghofar, A., \& Ain, C. (2015). Beberapa aspek biologi perikanan rajungan (Portunus pelagicus) di perairan Betahwalang dan sekitarnya. Jurnal Saintek Perikanan. 11(1), 62-71.

Oh, C.W, Hartnoll, R.G., \& Nash R.D.M. (1999). Population dynamics of the common shrimp, Crangon crangon (L), in Port Erin Bay, Isle of Man, Irish Sea. ICES Journal of Marine Science, 56, 718733.

Panggabean, A.S., Pane, A.R.P., \& Hasanah, A. (2018). Dinamika populasi dan tingkat pemanfaatan rajungan (Portunus pelagicus Linnaeus, 1758) di Perairan Teluk Jakarta. J.Lit.Perikan.Ind. 24(1), 73-85. DOI: http:// dx.doi.org/10.15578/jppi.1.1.2018.73-85.

Pauly, D. (1980). A selection of a simple methods for the assessment of the tropical fish stocks. FAO Fish. Circ. FIRM/C729. Roma. 54p.

Potter, I.C. \& de Lestang, S. (2000). Biology of the blue swimmer crab Portunus pelagicus in Leschenault Estuary and Koombana Bay, southwestern Australia. Journal of the Royal Society of Western Australia, 83, 443-458.

Premarathna, A.D., Rajapakse, R.P.V.J., Pathirana, E., Senaratne, V.P., Karunarathna , S.C., \& Jayasooriya, A.P. (2015). Nutritional analysis of some selected fish and crab meats and Fatty acid analysis of oil extracted from Portunus pelagicus. Int. Jour. Scientific \& Technology Research, 4(07), 197-201.
Prihatiningsih., \& Wagiyo, K. (2009). Sumber daya rajungan (Portunus pelagicus) di Perairan Tangerang. BAWAL. 2(6).273-282. DOI: http:// dx.doi.org/10.15578/bawal.2.6.2009.273-282.

Putri, M.R.A., Hartati, S.T., \& Satria, F. (2016). Kematian masal ikan dan Sebaran parameter kualitas air di Teluk Jakarta. BAWAL, 8(2), 77-90. DOI: ht t p://dx.doi.org/10.15578/ bawal.8.2.2016.77-90.

Sachoemar, S.I., \& Wahyono, H.D. (2007). Kondisi pencemaran lingkungan di Teluk Jakarta. JAI. 3(1), $1-14$.

Sara, L., Muskita, W.H., Astuti, O., \& Safilu. (2016). The reproductive biology of blue swimming crab Portunus pelagicus in Southeast Sulawesi Waters, Indonesia. AACL Bioflux, 9(5), 1101-1112.

Safaie, M., Shokri, M.R., Kiabi, B.H., \& Pazooki, J. (2015). Biomass, CPUE and Size frequency distribution of blue swimming crab Portunus segnis (Forskal, 1775) in coastal waters of the nothern Persian Gulf, Iran. Journal of the Marine BiologicalAssociation of the United Kingdom, 1-9.

Setiawan, R.Y., \& Habibi, A. (2010). Sea surface temperature cooling in the Indonesian Seas. Journal Ilmu Kelautan, 15(1), $42-46$.

Soegiarto, A. \& Soegiarto, K.A. (1977). Sekitar sejarah penelitian di perairan Teluk Jakarta dalam Teluk Jakarta Edit Malikusworo Hutomo, Kasijan Romimohtarto dan Burhanuddin. Proyek Penelitian sumberdya ekonomi. Lembaga Oseanologi Nasional. LIPI. Jakarta

Songrak, A., Bodhisuwan, W., \& Chaidee, T.T. (2013). Selectivity of traps for blue swimming crab in Trang Province. Maejo Int. J. Sci. Technol, 7, 36-42

Sparre, P., \& Venema, S.C. (1992). Introduksi Pengkajian Stok Ikan Tropis (p.438). Buku I: Manual. Organisasi Pangan dan Pertanian Perserikatan Bangsa-Bangsa. Pusat Penelitian dan Pengembangan Perikanan, Badan Penelitian dan Pengembangan Pertanian. Jakarta.

Svane, I., \& Hooper, G. ( 2004). Blue Swimmer Crab (Portunus pelagicus) Fishery, Fishery Assessment Report to PIRSA for the Blue Swimmer Crab Fishery Management Committee. South Australian Research and Development Institute.p.53 
Ubadillah, A., \& Hersoelistyorini, W. (2010). Kadar protein dan sifat organoleptik nugget rajungan dengan substitusi ikan lele (Clarias gariepinus). Jurnal Pangan dan Gizi, 1(2), 45-54. DOI: https:// doi.org/10.26714/jpg.1.2.2010.\%25p

Wagiyo, K. (2008). Sebaran Makrozoobenthos pada berbagai Tipe Sedimen, Lokasi dan Musim di Teluk Jakarta. Prosiding Seminar Nasional Kelautan IV Universitas Hang Tuah. Surabaya. Hal.III.53-57.

Wiyono, E.S \& Ihsan. (2018). Abundance, Fishing Season and Management Strategy for Blue Swimming Crab (Portunus pelagicus) in Pangkajene Kepulauan, South Sulawesi, Indonesia. Tropical Life Sciences Research, 29(1), 1-15. DOI: 10.21315/tlsr2018.29.1.1
Yuliani, R.L., Purwanti, E., \& Pantiawati, Y. (2015). Pengaruh Limbah Detergen Laundry Terhadap Mortalitas dan Indeks Fisiologi Ikan Nila (Oreochromis niloticus). P822-828. Biologi, Sains, Lingkungan, dan Pembelajarannya. Seminar Nasional XII Pendidikan Biologi. FKIP UNS.

Zairion, Y., Wardiatno., \& Fahrudin, A. (2015). Sexual maturity, reproductive pattern and spawning female population of the blue swimming crab, Portunus pelagicus (Brachyura: Portunidae) in East Lampung Coastal Waters, Indonesia. Indian Journal of Science and Technology, 8(7), 596-607. DOI: 10.17485/ijst/2015/v8i6/69368 
Lampiran 1. Daerah tangkapan rajungan (Portunus pelagicus)

Appendix 1. Fishing ground of blue swimmer crab(Portunus pelagicus)

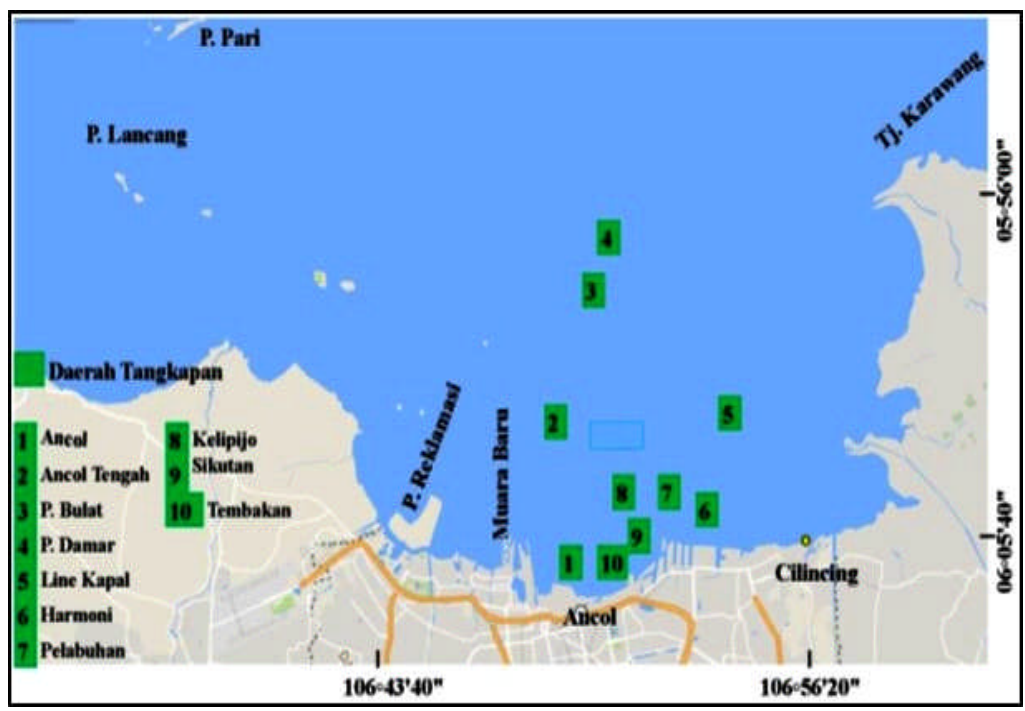

Lampiran 2. Indeks musim penangkapan rajungan di perairan Teluk Jakarta Appendix 2. Index fishing season of blue swimmer crab in the Jakarta Bay waters

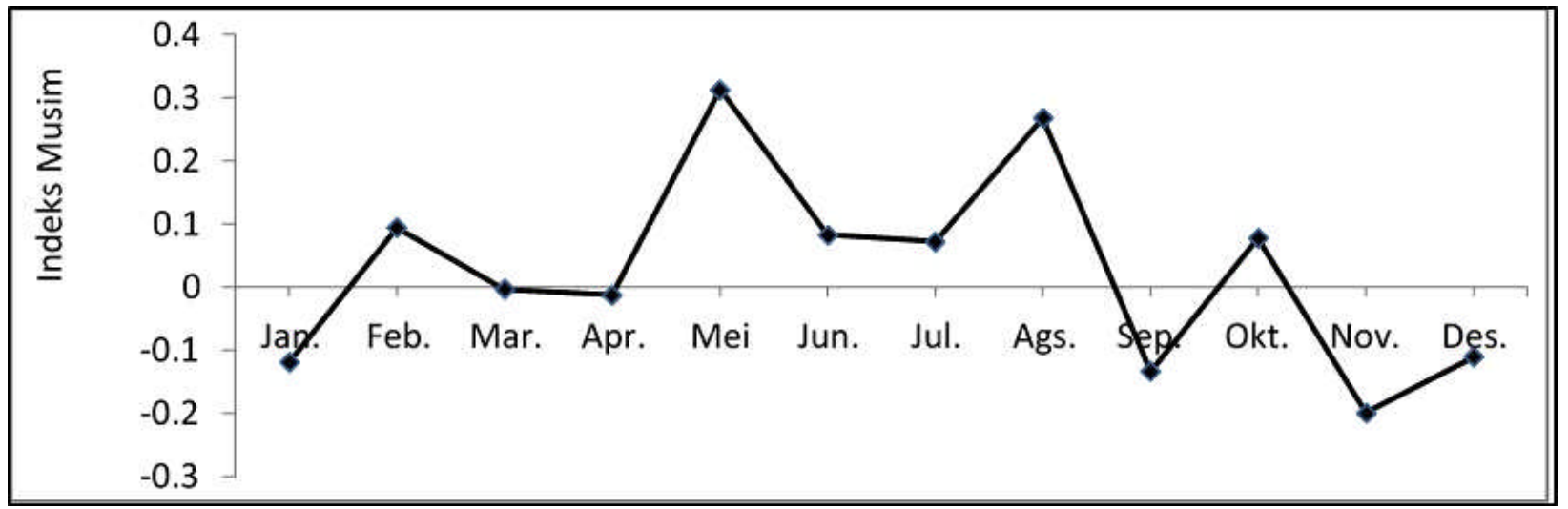

Lampiran 3. Hasil tangkapan per unit usaha (CPUE) rajungan; a) bulanan, b) tren penurunan tahunan di Cilincing.

Appendix 3. The catch per unit effort (CPUE) blue swimmer crab; a) monthly, b) the trend of annual decline in Cilincing.

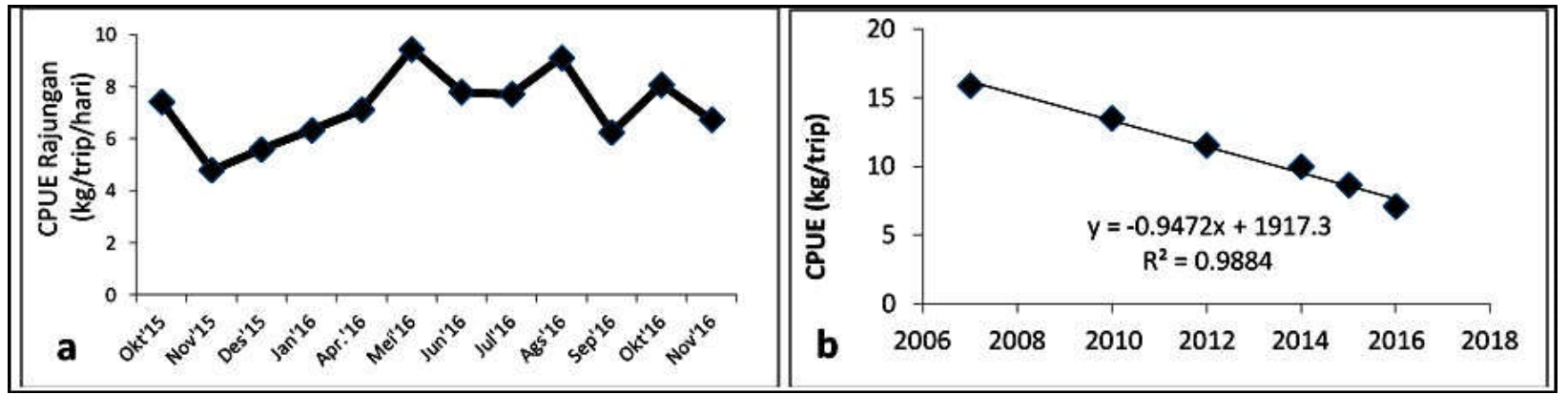


Lampiran 4. a). Produksi rajungan bulanan di Cilincing, b) Komposisi tangkapan jaring rajungan Appendix 4. a). Montly production of blue swimmer crab in Cilincing, b) Catch composition of bottom gillnets.

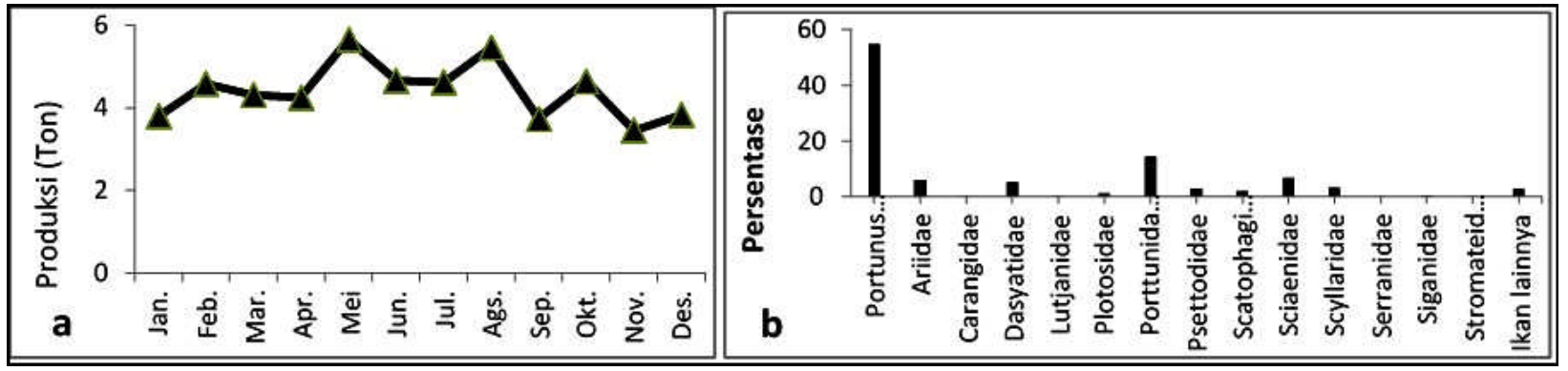

Lampiran 5. a). Frekuensi lebar karapas, b) Hubungan lebar karapas-berat, c) Sebaran spasial rajungan Appendix 5. a). The frequency of carapace length (a), the width-weight relationship (b), spasial distribution of carapace width(c) of blue swimmer crab

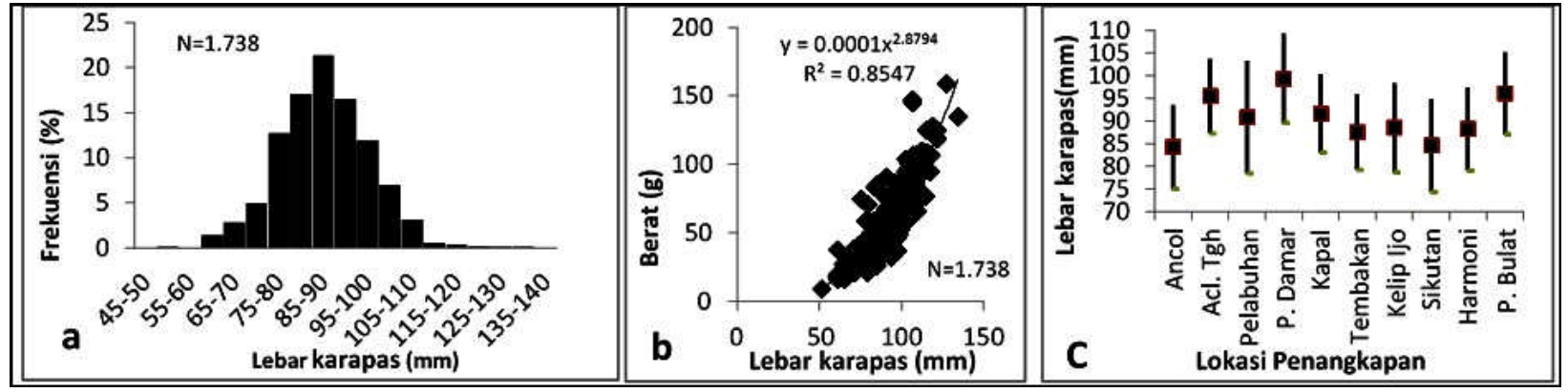

Lampiran 6. Nisbah kelamin rajungan, a)sebaran temporal, b)sebaran spasial Appendix 6. Sex ratio of blue swimmer crab, a) temporal distribution, b) spasial distribution

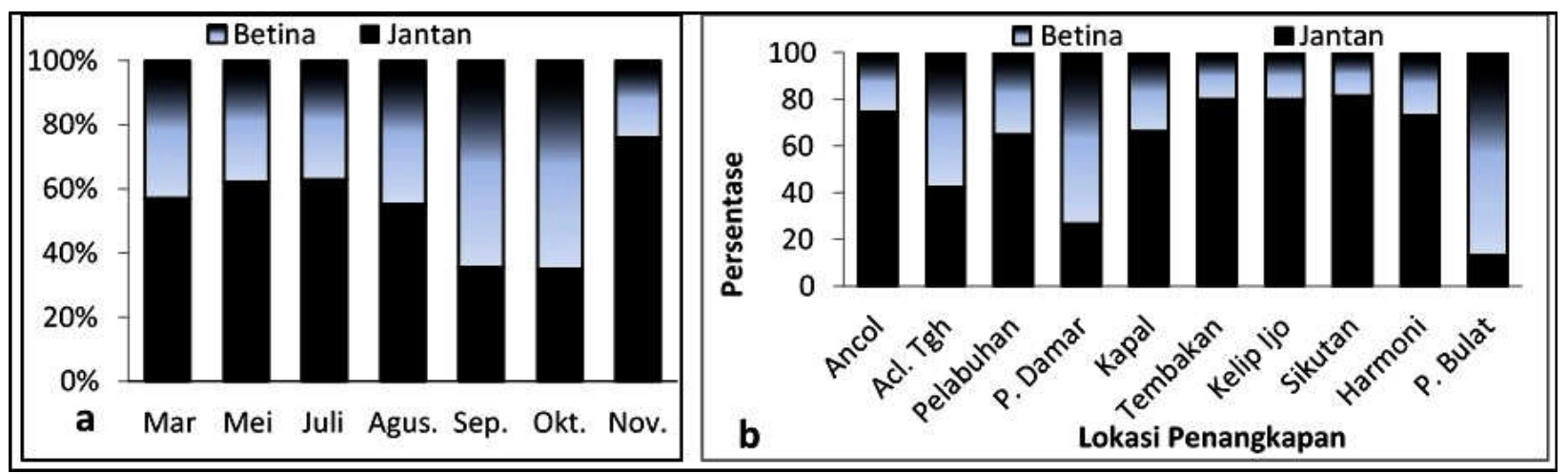

Lampiran 7. Tingkat kematangan gonad rajungan, a) sebaran temporal, b) sebaran spasial Appendix7. Gonad maturity of blue swimmer crab, a) temporal distribution, b) spasial distribution

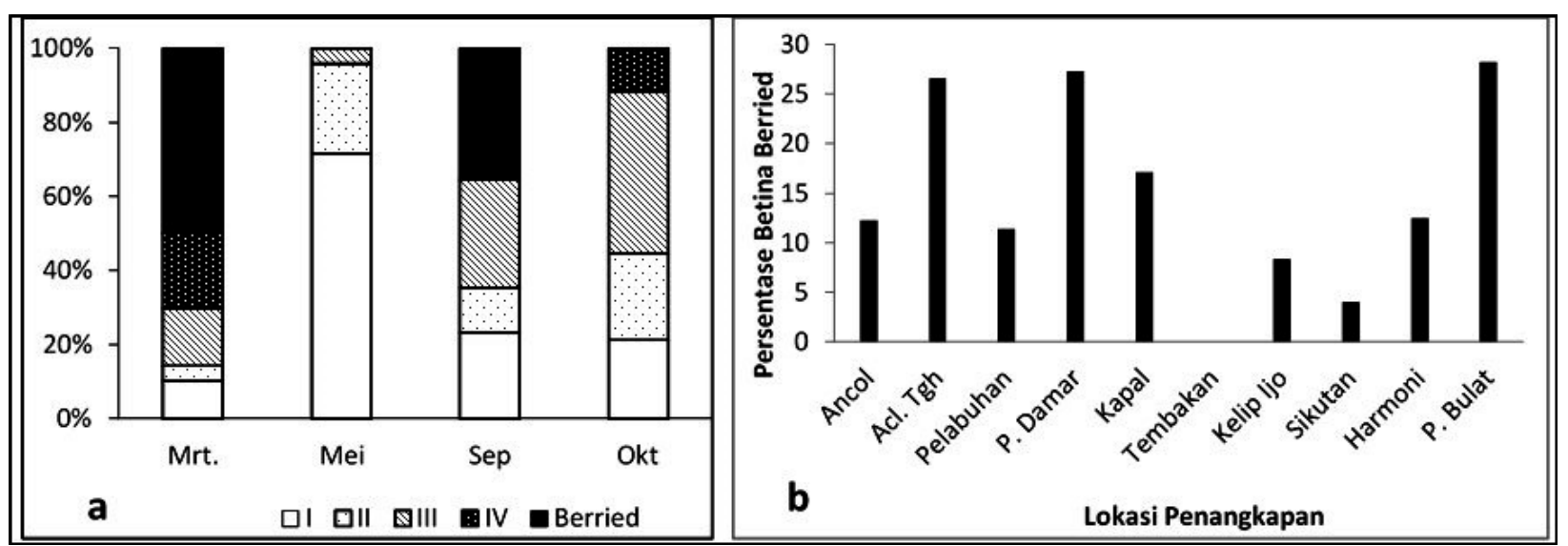


Lampiran 8. Kurva panjang karapas pertama tertangkap (a), kurva sebaran lebar karapas (b) dan konversi lebar karapas kedalam umur relatif (c) rajungan.

Appendix 8. The curva of first caught of carapace length (a) the curve of carapace width distribution (b) and carapace width-converted catch curve (c) of blue swimmer crab

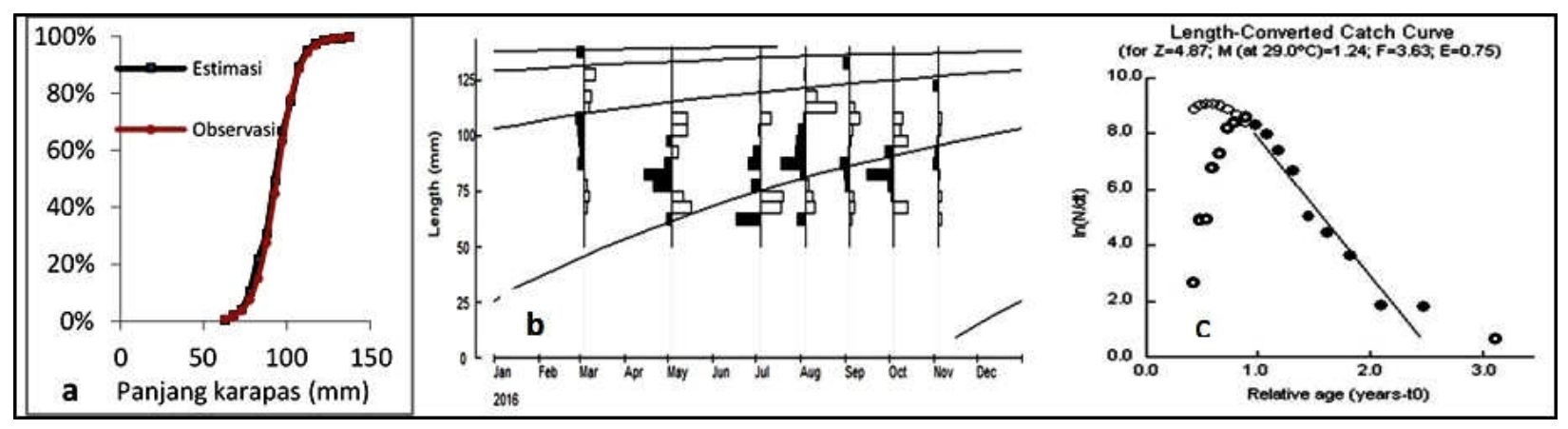

